\title{
Brackish Shrimp Farming in Northeastern Brazil: The Environmental and Socio-Economic Impacts and Sustainability
}

\author{
Tadeu Dote Sá ${ }^{1}$, Rommel Rocha de Sousa ${ }^{2}$, Ítalo Régis Castelo Branco Rocha ${ }^{2}$, \\ Gutemberg Costa de Lima ${ }^{2}$, Francisco Hiran Farias Costa ${ }^{2 *}$
}

${ }^{1}$ Geoconsult - Geology and Environment Consulting, Fortaleza, Brazil; ${ }^{2}$ Department of Fishing Engineering, Campus do Pici, Federal University of Ceará, Fortaleza, Brazil.

Email: "hiran1968@hotmail.com

Received October $6^{\text {th }}, 2013$; revised November $7^{\text {th }}, 2013$; accepted November $21^{\text {st }}, 2013$

Copyright (C) 2013 Tadeu Dote Sá et al. This is an open access article distributed under the Creative Commons Attribution License, which permits unrestricted use, distribution, and reproduction in any medium, provided the original work is properly cited. In accordance of the Creative Commons Attribution License all Copyrights (C) 2013 are reserved for SCIRP and the owner of the intellectual property Tadeu Dote Sá et al. All Copyright (C) 2013 are guarded by law and by SCIRP as a guardian.

\begin{abstract}
Despite the economic importance of farmed shrimp, a number of technical, environmental, economic and social problems have been widely reported in the international literature. This paper focuses on the environmental and socio-economic impacts of semi-intensive and intensive shrimp farming in the coastal region of Northeastern Brazil and the identification of options for sustainable production. In this Region, the total area dedicated to shrimp farming is approximately 18,500 ha, of which 5750 ha are located in Ceará State. The estuary of Jaguaribe river has the largest number of shrimp farms in the state of Ceará. Currently, the industry has 64 participating farms with a total area dedicated to shrimp farming of $2411.3 \mathrm{ha}$. In 2011, the total production was 13,110 tons of shrimp with an average yield of 6.3 ton $\mathrm{ha}^{-1} \cdot \mathrm{year}^{-1}$ in a pond area of 2071.2 ha. This industry employs 2350 people that represent $23.2 \%$ of jobs generated in the two municipalities where the Jaguaribe river estuary is inserted. Compared with other countries, Brazil has reduced its exports due to high cost inputs for shrimp farming. However, the Brazilian shrimp industry has benefited from high domestic prices, despite the decreases in international price of shrimp. In 2011, the prices for size category ranged between U\$ 4.67 - 6.04 for 80/100 (count of head-on shrimp), U\$ 4.95 - 6.60 for 70/80 and U\$ $5.85-8.10$ for 50/60. The major environmental impacts in this industry have focused on the water pollution and loss of mangroves. However, no change in parameters of water quality was observed during the period 2010-2012, indicating that this estuary has some capacity to process pond-derived nutrients while only 3.7 ha of mangrove forests were used to shrimp pond. The results of this investigation demonstrate that Brazilian shrimp industry requires improved management and development policy for a sustainable growth.
\end{abstract}

Keywords: Shrimp Farm; Mangroves; Impacts; Environmental; Penaeus vannamei

\section{Introduction}

In 2010, the total production of white shrimp Penaeus vannamei from world aquaculture was 2.7 million tons with a first sale value of U\$ 11 billion [1]. The rapid development of shrimp farming in many countries is a phenomenon of the last three decades as a result of industrial transformation and intensification of production patterns $[2,3]$. Shrimp farming has been a significant agro-based economic activity [4]. This multimillion dollar industry

${ }^{*}$ Corresponding author. plays an important role in the economic development of many tropical and sub-tropical countries because of the high economic returns $[5,6]$. However, there is evidence that sustainable production is limited partly by the carrying capacity of the coastal ecosystems supporting aquaculture [7]. Additionally, the rapid growth of this Industry in an unregulated and uncoordinated way has led to a number of environmental, technical, economic and social problems, which have been widely reported in international literature [2,8-10].

The conversion of sensitive coastal land, including 
mangroves, into shrimp ponds in many locations and periods, has been principal criticism to shrimp farming Industry [2,11-14]. In areas of intense shrimp farming, discharge waters from one farm mixed with supply waters used by neighboring farms, have resulted in pollution between farms and the spread of disease between shrimp populations [15-19]. However, different shrimp culture technologies have different environmental impacts. Extensive systems requiring large land areas have contributed most to mangrove clearance, while intensive systems have contributed more to pollution problems, through high stocking densities and feed and chemical inputs [2].

Brazil is the third largest producers of farmed white shrimp in Latin America. The Brazilian production was estimated at 70,000 tons with an estimated value greater than U\$ 280 million in 2010 [1]. In Brazil, semi-intensive and intensive shrimp farming began during the 1980s with introduction and culture of white shrimp $P$. vannamei. The northeast region of Brazil is responsible for around $97 \%$ of the national shrimp production [20]. The fast development of shrimp farms in this region has given rise to concerns about specific environmental legislation for the activity, environmental pollution and conflict with rural population. In the early $2000 \mathrm{~s}$, Brazilian shrimp aquaculture was responsible for the employment of 50,000 people [21], reducing the pressure against the development of the activity. However, the industry has been suffered a severe collapse due to disease outbreaks in 2003 $[22,23]$. This fact has caused a drastic reduction in the number of jobs, which has strengthened the movements against the shrimp industry.

In Brazil, the total area dedicated to shrimp farming approximates 18,500 ha of which 5750 ha are located in Ceará State [21]. The estuary of Jaguaribe river has the largest number of shrimp farms in the state of Ceará. In this estuary, the shrimp pond area increased from 820 ha in 2000 to 1640 ha in 2006 [24]. However, information about the positive or negative impacts of shrimp farms in this region is unknown. This article documents the dimensioning of the production area of shrimp farms using satellite images and geoprocessing techniques, and analysis of shrimp production, technical, economic, social and environmental aspects of shrimp farms in the estuary of Jaguaribe river.

\section{Material and Methods}

\subsection{Site Location}

The study area consisted of marine shrimp culture farms located in the hydrographic basin of Jaguaribe river. The Jaguaribe river is part of the Atlantic hydrographic region of Brazilian northeast, located in the East region of the Ceará State and represents the principal hydric reserve of the State with the enclosed area for its hydro- graphic basin comprehends approximately $80,000 \mathrm{~km}^{2}$. The Jaguaribe river estuary comprises an area of approximately $200 \mathrm{~km}^{2}$ and is characterized by having a great economic and ecological importance (Figure 1).

\subsection{Shrimp Farm Operations}

Shrimp aquaculture production consists mainly of white shrimp Penaeus vannamei and it takes place almost exclusively in earthen ponds. This analysis focuses on shrimp production in ponds with particular attention to the cultivation and harvesting phases in the production cycle. The cultivation phase includes post larvae (PL) stocking, feeding and pond water exchange. The harvest phase includes harvesting and pond emptying and treatment. A number of farming processes in these phases have potentially significant impact on the environment. The processes of pond treatment, inlet water treatment, feeding, water exchange, and final water discharge and sediment dredging were observed and described.

The methodology was based on field observations, interviews, and analysis of secondary data [25]. A survey carried in the period 2010-2012 involved visits to all shrimp farms. Interviews were conducted using a semistructured questionnaire. Interviewees included farm owners or managers, traders, processing firms and hatchery managers and government officials. Data analysis was based on field observations, interview transcriptions, and external sources including official documents, external sources and academic literature on the subject [26].

\subsection{Benefits and Problems of Shrimp Aquaculture}

All shrimp farms were visited to collect information about the macro-economic benefits and problems of shrimp aquaculture. The macro-economic benefits include the creation of direct formal jobs, seasonal jobs, indirect formal jobs including hatcheries and post-harvest, earning of foreign exchange, diversification of the economy, stimulation of backward and forward-linked sectors, inflow of direct investment and technological transfer. The negative aspects of shrimp aquaculture include technical, environmental, economic and social problems.

\subsection{Processing of Satellite Images}

This study started with the identification and location of shrimp farms using available satellite images with a resolution of 15 meters per pixel (Landsat Geocover of 19992000, CBERS of 2009-2010 and Google Earth). Due to the lack of images representing the region of shrimp farms were located, the images available in Google Earth with high-resolution were used. Afterwards, the images were overlapped in layers using digital aerial photographs edited by the Directorate of Hydrography and Navigation 


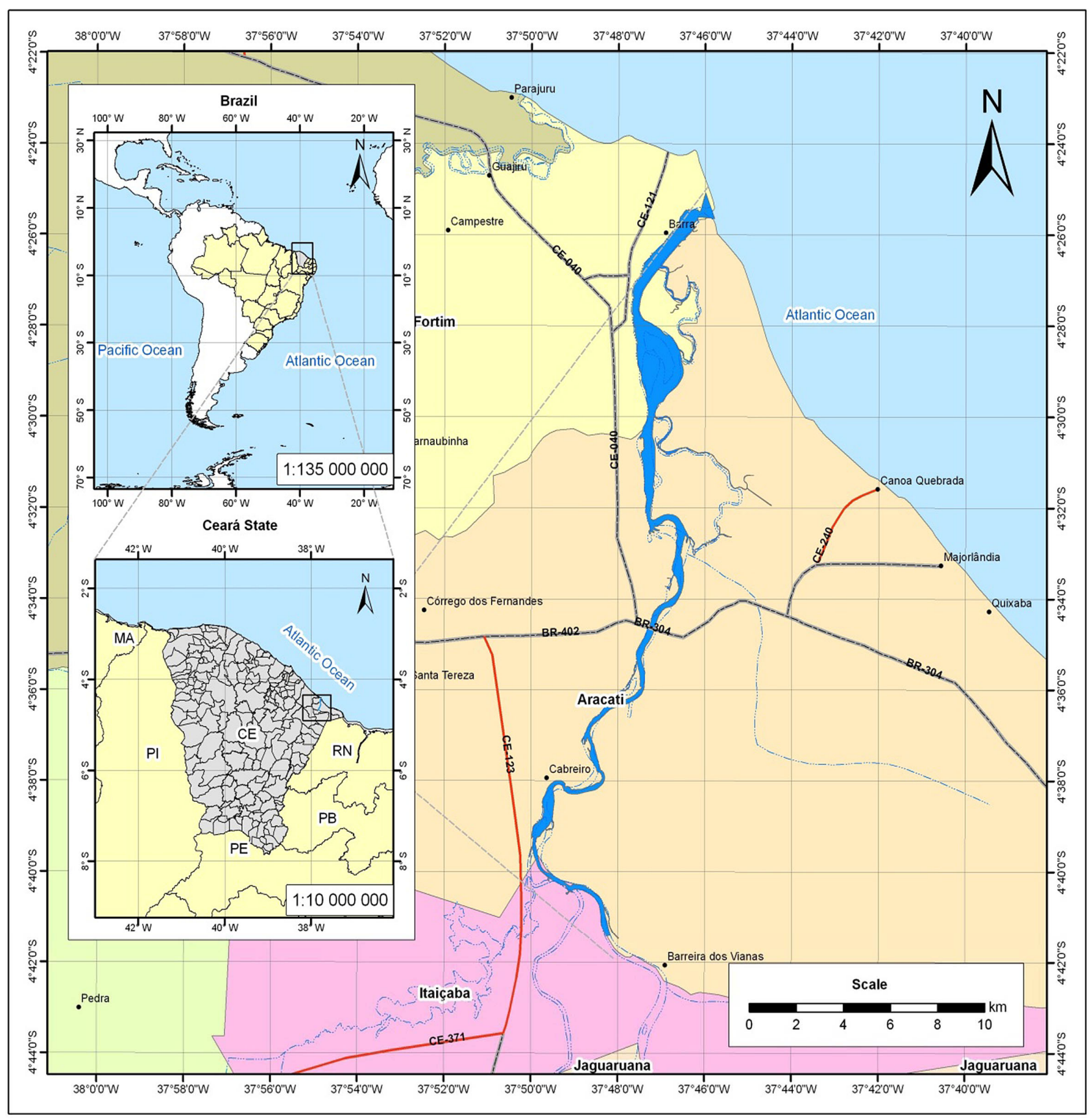

Figure 1. The study area: northeastern of Brazil.

(DHN) of Brazilian Navy in order to characterize the type of occupation and land use of the current aquaculture enterprises. These aerial photographs were obtained in the 1960s when there were no shrimp farms in Brazil. Subsequently, thematic maps in detail scales were developed by application of techniques digital interpretation of images and GIS, available in software SPRING 4.2 and ArcGIS 9.0. With the analysis and interpretation of the images, it was possible to map and survey the areas occupied by shrimp culture activity in the Jaguaribe river estuary.

\subsection{Water Sampling and Analysis}

From February 2010 to June 2012, thirty-three shrimp farms were visited to collect information about farming practices. During the shrimp production season, a total of 53 and 33 samples were collected from shrimp farms at the pump station (influent) and point of water discharge (effluent), respectively. Water quality parameters were analyzed in the water samples [27]. The parameters included: temperature, salinity, $\mathrm{pH}$, dissolved oxygen (DO), total ammoniacal nitrogen (TAN), ammonia, nitrate, 
nitrite, total phosphorus (TP), chlorophyll $a$, biochemical oxygen demand (BOD), turbidity and coliforms. The results of these analyses have been accomplished to the Ceará State Enviromental superintendency. Then, the focus was on an interpretation and synthesis of the results and their relevance to the environmental performance of semi-intensive and intensive shrimp farming.

The variables were analyzed separately to obtain statistical parameters (mean, standard deviation, minimum and maximum). Data were analyzed by an analysis of variance (ANOVA) followed by the post-hoc Duncan multiple range test. A probability level of $p<0.05$ was considered statistically significant.

\section{Results}

\subsection{Development and Characteristics of Shrimp Farming}

The number of companies in the Jaguaribe river estuary producing white shrimp Penaeus vannamei has increased during recent years. Currently, the industry has 64 participating farms. Shrimp farms can be divided into three categories: small ( $<30 \mathrm{ha}$ ), medium (between 30 and 100 ha) and large ( $>100$ ha) (Table 1). In this study, total area dedicated to shrimp farming was 2411.3 ha in 2010

(Figure 2), while the pond area was 2071.2 ha (Table 1). The more common management system in the region is the semi-intensive type which occurs in $65.6 \%$ of the farms, while the intensive comprise $34.4 \%$. Details on the management and characteristics of shrimp farms are summarized in Table 2. The shrimp farms operated all year round with 2.5 to 4.7 cycles year ${ }^{-1}$. In semi-intensive system, the stocking density of post-larval ranges from $15-30$ individuals $\mathrm{m}^{-2}$ in $1.0-10.0$ ha ponds. During crop cycles, 3.2 - 4.7 crops are performed for year, resulting in a yield of 4.6 ton $\cdot \mathrm{ha}^{-1}$.year ${ }^{-1}$. The application of fertilizers, supplementary feeding and water exchange of $0 \%-5 \%$ are characteristic of this system. The feed conversion ratio (FCR) varies depending of feed quality and the management, generally it is lower $(1.0-1.5)$. Commercially available pelleted feed (several companies) for $P$. vannamei are used in all shrimp farms. Protein content of the feed ranged from $30 \%$ to $40 \%$.

The intensive culture system is characterized by the combination of high initial stocking densities (30 - 100 individuals $\mathrm{m}^{-2}$ ) and major feeding rates. During crop cycles, 2.5 - 3.5 crops are performed for year, resulting in a yield of 9.2 ton $\mathrm{ha}^{-1}$.year ${ }^{-1}$. Depending on local conditions and the stage of grow-out, cycle feeding with commercial feed ( $35 \%-40 \%$ protein) takes place and there is a regular water exchange of $3 \%-30 \%$ of the pond volume per day that varied according to the stage of the production cycles. Constant use of mechanical stirrers ensures that aerobic conditions are maintained. FCR is also variable in this type of system, but it is possible to assume that 1.8 is a representative value.

The range size of farms in the Jaguaribe river estuary vary from 1 to 630 ha, with a mean estimated at 32.4 ha. The pond size also is variable ( 1 and $32.5 \mathrm{ha}$ ), 2 - 5 ha being predominant. The mean stocking density for intensive shrimp farms is $40 \mathrm{PL} \cdot \mathrm{m}^{-2}$ and for the semiintensive $20 \mathrm{PL} \cdot \mathrm{m}^{-2}$. In $2010-2012$, the survival was normally in the range of $51.2 \%-85.9 \%$ from stocking to harvest. The total production in 2011 was 13,110 tons in a pond area of 2071.2 ha with an average yield of 6.3 ton $\cdot$ ha $^{-1} \cdot$ year $^{-1}$.

The shrimp culture industry located in the Jaguaribe river estuary has generated 1.14 direct formal jobs, seasonal jobs, indirect formal jobs including hatcheries and post-harvest per hectare. Shrimp farms are responsible for the generation of 1186 direct formal jobs and 150 seasonal jobs related to shrimp harvest. In this region, there are two hatcheries and one processing plant that generate 149 and 420 direct formal jobs, respectively. The other secondary activities including buyers of shrimp and small processing plants have generated 451 direct formal jobs. The employments generated by fertilizers and feed industries were not considered because they are not located in the region of Jaguaribe river estuary. The local population is the main beneficiary from the creation of jobs. However, jobs requiring qualifications are normally occupied by outsiders.

Additionally, the shrimp culture industry located in the Jaguaribe river estuary has contributed to the strengthening and diversification of the local economy, increasing in the number of jobs in other sectors of industry and commerce. As an example, the major shrimp farm that operates in this region has opened up new companies, creating 77 additional jobs. This industry has also induced the operation of a federal school for training of young aquafarmers.

Table 1. Characteristics of the shrimp farms by size operation.

\begin{tabular}{|c|c|c|c|c|c|c|c|c|}
\hline \multirow[b]{2}{*}{ Production system } & \multicolumn{2}{|c|}{ Small } & \multicolumn{2}{|c|}{ Medium } & \multicolumn{2}{|c|}{ Large } & \multicolumn{2}{|c|}{ Total } \\
\hline & $\begin{array}{l}\text { Number of } \\
\text { companies }\end{array}$ & Area (ha) & $\begin{array}{l}\text { Number of } \\
\text { companies }\end{array}$ & Area (ha) & $\begin{array}{l}\text { Number of } \\
\text { companies }\end{array}$ & Area (ha) & $\begin{array}{l}\text { Number of } \\
\text { companies }\end{array}$ & Area (ha) \\
\hline Semi-intensive & 37 & 260.1 & 3 & 154.0 & 2 & 880.0 & 42 & 1294.1 \\
\hline Intensive & 10 & 92.0 & 11 & 535.1 & 1 & 150.0 & 22 & 777.1 \\
\hline Total & 47 & 351.1 & 14 & 689.1 & 3 & 1030.0 & 64 & 2071.2 \\
\hline
\end{tabular}



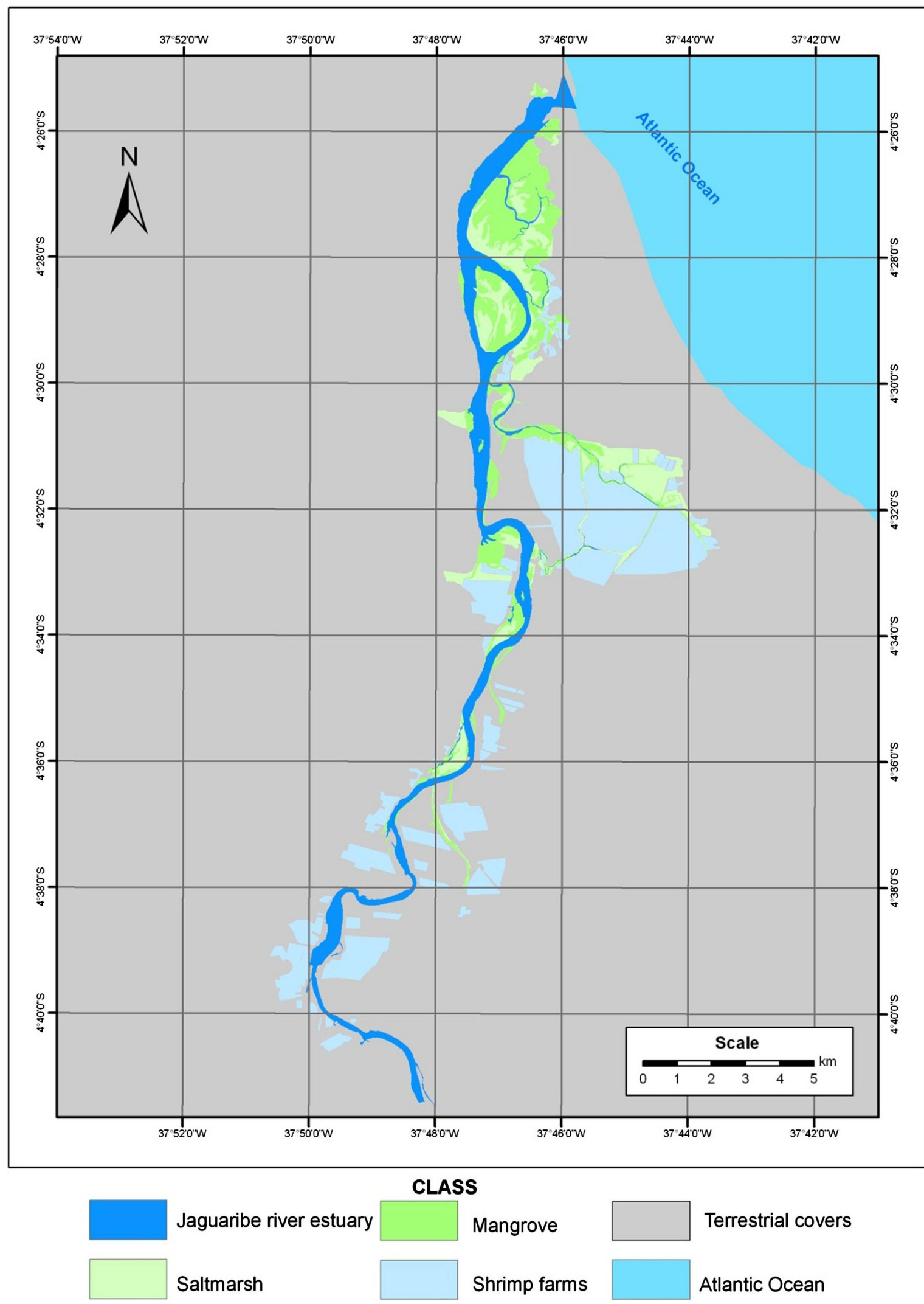

Figure 2. Thematic map of coastal wetland distribution in Jaguaribe river estuary. Land cover categories obtained by digitisation and by means of a supervised classification for Landsat Geocover of 1999-2000, CBERS of 2009-2010 and Google Earth images. 
Table 2. Characteristics of the different types of shrimp aquaculture practices.

\begin{tabular}{|c|c|c|}
\hline \multirow{2}{*}{ Characteristics } & \multicolumn{2}{|c|}{ Intensity of farming systems } \\
\hline & Semi-intensive & Intensive \\
\hline Pond size (ha) & $1.0-32.5$ & $1.3-4.7$ \\
\hline Stocking density $\left(\mathrm{PL} \cdot \mathrm{m}^{-2}\right)$ & $15-30$ & $30-100$ \\
\hline Survival rate $(\%)$ & $56.1-85.9$ & $51.2-82.3$ \\
\hline Water exchange (\%) & $0-5$ & $3-30$ \\
\hline Aeration $\left(\mathrm{HP} \cdot \mathrm{ha}^{-1}\right)$ & $0-4$ & $4-20$ \\
\hline Yield (ton $\cdot \mathrm{ha}^{-1} \cdot \mathrm{yr}^{-1}$ ) & 4.6 & 9.2 \\
\hline Number of cropsyr ${ }^{-1}$ & $3.2-4.7$ & $2.5-3.5$ \\
\hline Production (ton $\cdot$ year $^{-1}$ ) & 5952.9 & 7157.5 \\
\hline Fertilizers used $\left(\right.$ ton $\left.\cdot \mathrm{ha}^{-1} \cdot \mathrm{yr}^{-1}\right)$ & Urea $<0.25$, TSP $<0.03$ & Urea $<0.50, \mathrm{TSP}<0.10$ \\
\hline Feed consumption (ton $\cdot \mathrm{yr}^{-1}$ ) & 7083.9 & 11953.0 \\
\hline Feed used & Natural and pelleted feed & Pelleted feed \\
\hline Protein feed $(\%)$ & $40-30$ & $40-35$ \\
\hline FCR & $1.01-1.37$ & $1.32-2.02$ \\
\hline Chemicals used & Yes & Yes \\
\hline Direct formal jobs (persons $\cdot \mathrm{ha}^{-1}$ ) & 0.52 & 0.67 \\
\hline Direct seasonal jobs (persons $\left.\cdot \mathrm{ha}^{-1}\right)^{*}$ & \multicolumn{2}{|c|}{0.07} \\
\hline Indirect jobs (persons $\left.\cdot \mathrm{ha}^{-1}\right)^{*}$ & \multicolumn{2}{|c|}{0.42} \\
\hline Disease problems & Rare (IMNV and IHHNV) & Rare (IMNV and IHHNV) \\
\hline Operational costs & Moderate to high & Moderate to high \\
\hline Environmental impact & Relatively little & Relatively little \\
\hline Social implications & Moderate to high & Moderate to high \\
\hline Economic proliferation & Commercial & Commercial \\
\hline Sustainability concerns & Moderate to low & Moderate to low \\
\hline
\end{tabular}

*The number of jobs was calculated the total area of shrimp farming (2071.2 ha).

Currently, the states of São Paulo, Rio de Janeiro, Minas Gerais, Bahia, Ceará and Pernambuco are thought to be largest shrimp consumers in Brazil, with practically $100 \%$ of production directed to the domestic market. Shrimp producers realize sales to processing plants. Afterwards, depending on commercial demand, processed shrimp is removed from the storage chambers and shipped by land to consuming centers in Brazil. However, there are some direct sales to other customers such as supermarket chains, stores, hotels and restaurants.

\subsection{Assessment of Land Cover and Land Use}

Polygons for Jaguaribe river estuary, saltmarsh, mangrove, shrimp farms, terrestrial covers and the Atlantic ocean were digitised on-screen, rasterised, and overlaid on the images before the classification procedure that outputs thematic map with the cover and land use categories (Figures 2 and 3). The results obtained from digitising the shrimp farms on the Landsat Geocover and CBERS scene revealed a total of 64 shrimp farms or shrimp culture systems covering almost 2411.3 ha distributed close to the Jaguaribe river estuary. Although existing shrimp farms cover only 2411.3 ha of land in the study area, the potential for expanding shrimp farms should take into consideration further political and environmental issues, since most of the suitable areas for shrimp farming are agricultural land.

Calculations showed that in the period 1967-2010, the area of mangrove increased from 584.2 ha to 1273.0 ha, although the movement of dunes on the right bank of the Jaguaribe river have contributed to a reduction in mangrove (Figure 3).

\subsection{Assessment of Water Quality}

The quality of water and subsequent effects of shrimp aquaculture in the coastal environment were evaluated by analyzing the parameters mentioned above in the sampling stations selected along the inlet and outlet points. The results of the water quality measurements included in this study are shown in Table 3.

In all the samplings for the influent and effluent from shrimp ponds in the Jaguaribe river estuary, the temperature did not vary along the years and normal seasonal variation was observed. There was no significant difference in water temperature between the pump station (influent) and point of water discharge (effluent). Similarly, 


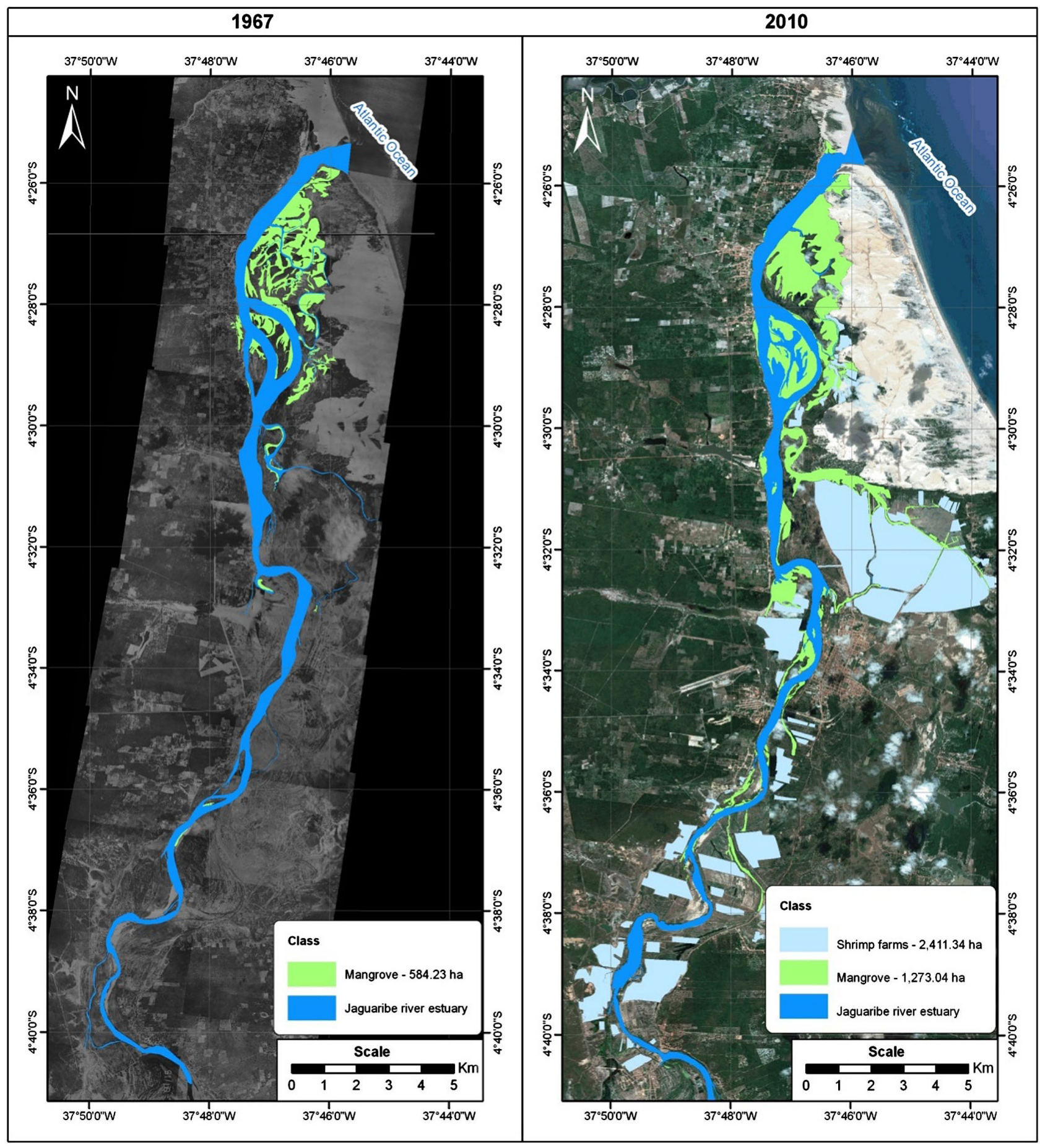

Figure 3. Thematic maps and area estimations of coastal wetland distribution in Jaguaribe river estuary. Land cover categories obtained by digitisation and by means of a supervised classification for aerial photographs of 1967, Landsat Geocover of 1999-2000, CBERS of 2009-2010 and Google Earth images.

there were no significant differences in water salinity, $\mathrm{pH}$ and dissolved oxygen among influent and effluent water. However, TAN, ammonia, nitrate, nitrite, total phosphorrus, chlorophyll $a$, BOD, turbidity and coliforms were significantly higher in point of water discharge than pump station.

\section{Discussion}

\subsection{Development and Characteristics of Shrimp Farming}

The total area dedicated to shrimp farming in the Jaguaribe river estuary was $1676.78 \mathrm{ha}$, in 2005 [28] and 1640 ha 


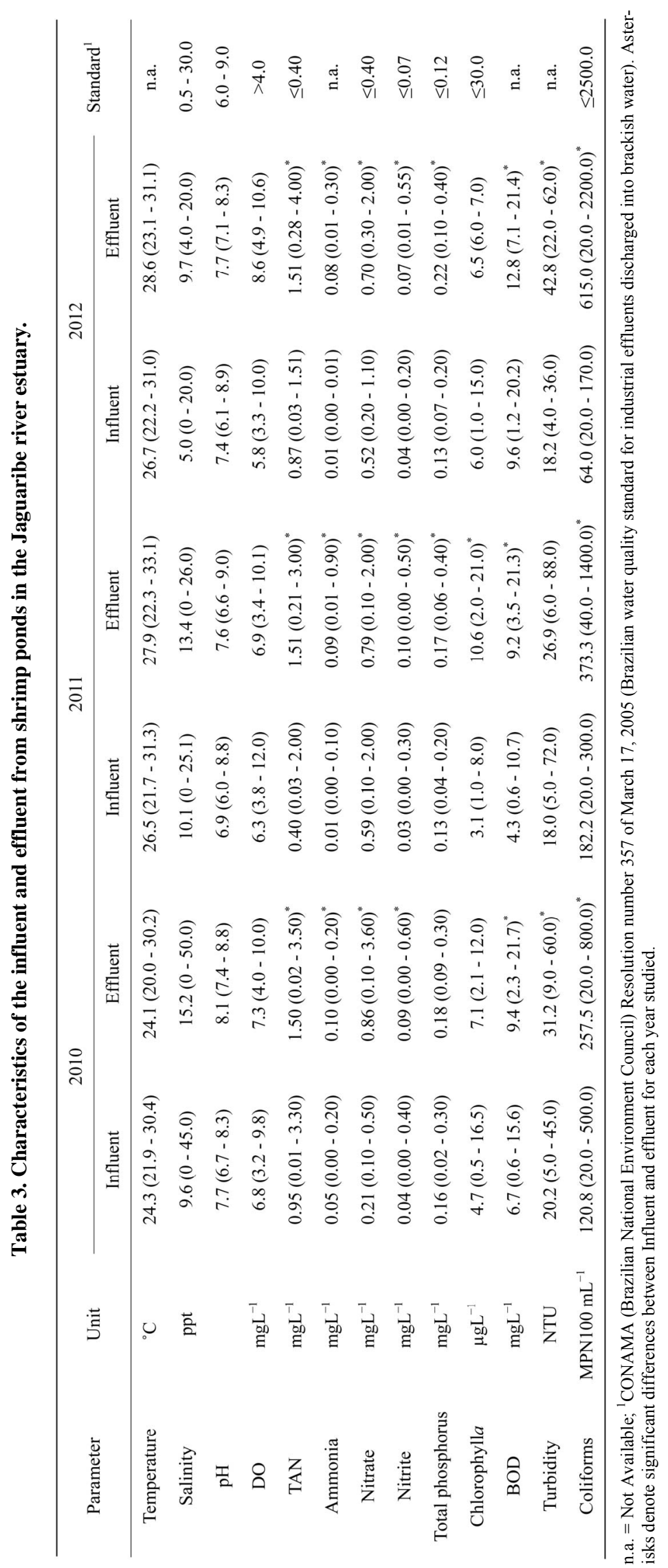


in 2006 [24]. Currently,total area dedicated to shrimp farming was $2,411.3 \mathrm{ha}$, representing a $47.0 \%$ increase compared with 2006 and of $43.8 \%$ with respect to 2005 .

Farming systems have gradually shifted from extensive traditional systems to improved extensive, semi-intensive and intensive production that are classified according to the pond size, water use, capital, labor, feed and chemicals used, and stocking densities [29]. In the Jaguaribe river estuary, semi-intensive shrimp culture utilizes pond enclosures that are smaller than traditional farms ( $1-8$ hectares), but this system provides significantly higher yields $\left(1-5\right.$ ton $\left.\cdot \mathrm{ha}^{-1} \cdot \mathrm{yr}^{-1}\right)$, while intensive shrimp aquaculture practices are typified by high stocking densities in aerated ponds $(1-5$ hectares $)$ and high production rates $\left(6-15\right.$ ton $\left.\cdot \mathrm{ha}^{-1} \cdot \mathrm{yr}^{-1}\right)$.

Since 2003, Brazilian shrimp cultivation has been hindered by disease in many regions $[22,30]$. The pandemic due to the penaeid virus IMNV has cost the Brazilian penaeid shrimp industry millions of dollars in lost crops, jobs, and export revenue [31]. Despite the expansion in the production area in the last years, diseases have not been a regular occurrence in the Jaguaribe river estuary shrimp farms in 2010-2012 [23,32]. IMN disease occurs principally in the rainfall period that was more intense for the period 2003-2009 than in 2010-2012. Diseases are associated more intensely with environmental changes than with the intensification of farms [33-35]. Moreover, poor water quality, associated with unplanned and uncontrolled farming, has increased the incidence of diseases and reduced production [36]. Unfortunately, the shrimp farms in the Jaguaribe river estuary have not implemented biosecurity plans, best management practices (BPM) and the use of certified postlarvae despite of the diseases and other technical problems. Despite of diseases are a recognized problem, the industry and Brazilian government are not using a SPF (specific pathogen-free) shrimp and Code of Conduct certifications. This case is completely different to observed situation in Thailand where approximately 18,000 shrimp/fish hatcheries and farms are certified for Good Aquaculture Practice/Code of Conduct by government in Thailand [37]. Additionally, due to its high costs and lack of preparation of shrimp farmers, it is still estimated that most farms do not have their effluents treated.

In the Jaguaribe river estuary, shrimp farms operated all year round with various cycles per year. On the other hand, in other countries the tendency has been to reduce the number of cycles per year due to the decreased crops during cold months [34,37-39].

The shrimp culture industry located in the Jaguaribe river estuary employs 2350 people that represent $23.2 \%$ of jobs generated in the two municipalities where the Jaguaribe river estuary is inserted. Therefore, this Industry contributes significantly to rural employment as ob- served in other developing countries [4,40]. The shrimp culture in Ecuador has transformed the regional balance of the economy with respect to production, employment and habitation [40]. Similarly, the economic benefits of shrimp aquaculture in Asia are well recognized including employment opportunities [36,41,42]. Additionally, this industry contributes to poverty reduction and food security, as well as generates employment from seed collectors to exporters [43].

However, it is not surprising that the growth of shrimp farming has generated mounting criticism of its socioenvironmental consequences, including the marginalisation of the rural poor, their increasing landlessness, breakdown of traditional livelihood support systems, increaseing poverty, diminishing food security, and the transfer of land and wealth to local and national élites [2]. These problems have been reported in several producing countries $[2,44-47]$. In the Jaguaribe river estuary, the negative aspects of shrimp aquaculture include the prohibition of local populations of their traditional access to mangroves, the decline in food security, the marginalization of coastal communities and the unemployment due to the abandonment of shrimp farms [48]. However, evidence for these cases are not presented objectively by author.

In the period 2003-2010, the competitiveness of Brazilian farmed shrimp exports were affected by IMNV disease, US anti-dumping process and the strengthening of the Brazilian currency. Consequently, the exports decreased from 58,500 tons in 2003 to 1600 tons in 2010 [21]. Brazilian farmed shrimp production has remained constant in the last years but exports have fallen sharply and almost all production is now consumed domestically [25].

Compared with other countries, Brazil has high cost inputs for shrimp farming. However, the Brazilian shrimp industry has benefited from high domestic prices, despite of decreases in international price of shrimp due to import restrictions and high demand in the domestic market $[3,21,49,50]$. In 2011, the prices for size category ranged between U\$ $4.67-6.04$ for 80/100 (count of head-on shrimp), U\$ $4.95-6.60$ for $70 / 80$ and U\$ $5.85-8.10$ for $50 / 60$. These prices are $40 \%-50 \%$ higher than the practiced prices by farmers in Asia [51].

\subsection{Assessment of Land Cover and Land Use}

The use of satellite images has permitted monitoring and mapping of areas that require attention concerning the natural resource management [52-54]. Aerial survey techniques provide a level of details that allow the visualization of the landscape according to its structure and spatial-temporal distribution. The use of this tool is justified by its low cost and generation of digital data, which can be easily incorporated into a GIS database. 
In many countries, the rapid expansion of shrimp farming has caused extensive destruction of mangrove ecosystems $[55,56]$. The destruction of part of the mangrove area was documented during this study. These habitats are legally protected and perform important ecological and economic functions, such as structural protection against the erosion of the coast, hydrological regulation, and shelter for biota. However, shrimp farms located in the Jaguaribe river estuary have been constructed in less than $0.2 \%$ (3.7 ha) of mangrove areas. Similarly, for the northern coast of Sinaloa (Mexico), a land cover changedetection analysis, with Landsat images, outputs that $75 \%$ of the shrimp farming in this region has been built on saltmarshes while less than $1 \%$ was constructed on mangrove areas [57].

\subsection{Assessment of Water Quality}

The water quality of shrimp farm effluent depends on a number of factors, including pond soil type, quality of influent water, stage of grow out season and management practices employed [58]. Water pollution is largely associated with the use and discharge of water in shrimp ponds [29]. Common problems in the open water exchange system include phytoplankton crashes, deteriorated pond bottoms and bacterial diseases [59].

The quality of water and subsequent effects of shrimp aquaculture in the coastal environment were evaluated by analyzing the parameters mentioned above in the sampling stations selected along the inlet and outlet points. The physical, chemical and biological parameters of water during the monitoring period were maintained within the Brazilian water quality standard for industrial effluxents discharged into brackish water except for TAN (convert to ammonia), nitrate, nitrite and total phosphorrus. However, Brazilian water quality standards for industrial effluents discharged are more restrictive than BAP standards (Global Aquaculture Alliances Best Aquaculture Practices Standards). Brazilian water quality standards for TAN and total phosphorus are $\leq 0.4 \mathrm{mg} \cdot \mathrm{L}^{-1}$ and $\leq 0.12 \mathrm{mg} \cdot \mathrm{L}^{-1}$, respectively, while for BAP standards are $\leq 5.0 \mathrm{mg} \cdot \mathrm{L}^{-1}$ and $\leq 0.5 \mathrm{mg} \cdot \mathrm{L}^{-1}$, respectively. Various studies with monitoring of effluent and influent water quality in shrimp farms report similar results [29,38,60-64]. Additionally, several researches have demonstrated effluent water from shrimp ponds typically contains elevated concentrations of dissolved nutrients compared to influent water $[29,61,62,64]$.

On the other hand, the values of each environmental parameter remained stable during the period 2010-2012 indicating the capacity of the estuary to recycle nutrients. For example, TAN levels measured in the influent did not differ significantly during the years 2010 (mean 0.95 $\mathrm{mg} \cdot \mathrm{L}^{-1}$, ranging between $\left.0.01-3.30 \mathrm{mg} \cdot \mathrm{L}^{-1}\right), 2011$ (mean $0.40 \mathrm{mg} \cdot \mathrm{L}^{-1}$, ranging between $0.03-2.00 \mathrm{mg} \cdot \mathrm{L}^{-1}$ ) and 2012 (mean $0.87 \mathrm{mg} \cdot \mathrm{L}^{-1}$, ranging between $0.03-1.51$ $\mathrm{mg} \cdot \mathrm{L}^{-1}$ ). The mangrove estuaries have some capacity to tolerate periodic inputs of effluent from intensive shrimp ponds [60]. The authors suggest that the effluent can be dissipated by tides and assimilated and/or mineralized by the estuarine. The water quality was analyzed over a three-year period in a mangrove estuary receiving periodic inputs of effluent from adjacent shrimp ponds, and in two adjacent, non-impacted estuaries, in Australia [60]. The authors concluded that tidal mangrove estuaries have some capacity, at least over short spatial and temporal scales, to process intermittent inputs of pond-derived nutrients. However, strong contrasts in physical and chemical variables were evident between the influent and effluent creeks and between empty, full and harvest stages of a shrimp farm in same estuary [62]. According the authors, it was evident that the receiving environment in this study had been influenced as a result of waste from a shrimp farm.

\section{Conclusions}

This paper has assessed the environmental and socioeconomic impacts of Penaeus vannamei shrimp farming and discussed sustainable production techniques for Northeastern Brazil. Northeastern Brazil is a region with environmental limitations due to the semiarid climate and restrictions in water supply. However, this region is the best position to shrimp culture. The brackish water shrimp industry in the Jaguaribe river estuary is dominated by semi-intensive and intensive culture systems with a pond area of 2071.2 ha and an average annual yield of 6.3 ton $\mathrm{ha}^{-1}$. This industry has provided regular and additional employment to rural people, generating 1.14 jobs $\mathrm{ha}^{-1}$. Currently, pandemics caused by viruses have not resulted in economic losses of shrimp farming industry in this Region. On the other hand, unfortunately, on-farm biosecurity protocols have not been used to prevent the introduction or re-introduction of specific pathogens like WSSV or IMNV, respectively. Despite a number of positive aspects of shrimp farming, this industry has negative environmental impacts. The most important environmental problems caused by shrimp farming are associated with mangrove deforestation and water pollution. However, the use of satellite images indicates that about $99.8 \%$ of the shrimp farms in the Jaguaribe river estuary have been constructed predominantly on saltmarshes and other coastal land and the remaining $0.2 \%$ were developed on mangrove areas. Moreover, no change in parameters of water quality was observed during the period 2010-2012, indicating that this estuary has some capacity to process pond-derived nutrients. Finally, to further growth and intensification of shrimp farming and reduce 
the negative impacts associated with this industry, the use of breeding programs, SPF postlarvae, biosecure environments with physical barriers, pond treatment, inlet water treatment, treatment and reuse of effluent is necessary.

\section{Acknowledgements}

This research received support by Federal University of Ceará, CAPES Brazilian Coordination for the Improvement of Higher Education Personnel and Ministry of Fisheries and Aquaculture (Brazil).

\section{REFERENCES}

[1] FAO, "FAO Fisheries Department, Fishery Information and Statistics Unit," FISHSTAT Plus Version 2.3.2, Database Aquaculture Production 1950-2010, 2012.

[2] A. E. Neiland, N. Soley, J. B. Varley and D. J. Whitmarsh, "Shrimp Aquaculture: Economic Perspectives for Policy Development," MarinePolicy, Vol. 25, No. 4, 2001, pp. 265-279. http://dx.doi.org/10.1016/S0308-597X(01)00017-3

[3] L. Lebel, R. Mungkung, S. H. Gheewala and P. Lebel, "Innovation Cycles, Niches and Sustainability in the Shrimp Aquaculture Industry in Thailand," Environmental Science and Policy, Vol. 13, No. 4, 2010, pp. 291302. http://dx.doi.org/10.1016/j.envsci.2010.03.005

[4] M. Islam and J. B. Braden, "Bio-Economic Development of Floodplains: Farming versus Fishing in Bangladesh," Environment and Development Economics, Vol. 11, No. 1, 2006, pp. 95-126. http://dx.doi.org/10.1017/S1355770X0500269X

[5] P. Vandergeest, "Certification and Communities: Alternatives for Regulating the Environmental and Social Impacts of Shrimp Farming," World Development, Vol. 35, No. 7, 2007, pp. 1152-1171. http://dx.doi.org/10.1016/j.worlddev.2006.12.002

[6] M. S. Islam, "From Pond to Plate: Towards a TwinDriven Commodity Chain in Bangladesh Shrimp Aquaculture," Food Policy, Vol. 33, No. 3, 2008, pp. 209-223. http://dx.doi.org/10.1016/j.foodpol.2007.10.002

[7] I. Csavas, "Important Factors in the Success of Shrimp Farming," World Aquaculture, Vol. 25, No. 1, 1994, pp. 34-56.

[8] G. J. Graaf and T. T. Xuan, "Extensive Shrimp Farming, Mangrove Clearance and Marine Fisheries in the Southern Provinces of Vietnam," Mangroves and Salt Marshes, Vol. 2, No. 3, 1998, pp.159-166. http://dx.doi.org/10.1023/A:1009975210487

[9] N. Kautsky, P. Rönnbäck, M. Tedengren and M. Troell, "Ecosystem Perspectives on Management of Disease in Shrimp Pond Farming," Aquaculture, Vol. 191, No. 1-3, 2000, pp. 145-161. http://dx.doi.org/10.1016/S0044-8486(00)00424-5

[10] F. Páez-Osuna, "The Environmental Impact of Shrimp Aquaculture: Causes, Effects, and Mitigating Alternatives," Environmental Management, Vol. 28, No. 1, 2001, pp. 131-140. http://dx.doi.org/10.1007/s002670010212

[11] F. Páez-Osuna, S. R. Guerrero-Galván and A. C. RuizFernández, "The Environmental Impact of Shrimp Aquaculture and the Coastal Pollution in Mexico," Marine Pollution Bulletin, Vol. 36, No. 1, 1998, pp. 65-75. http://dx.doi.org/10.1016/S0025-326X(98)90035-2

[12] L. Lebel, N. H. Tri, A. Saengnoree, S. Pasong, U. Buatama and L. K. Thoa, "Industrial Transformation and Shrimp Aquaculture in Thailand and Vietnam: Pathways Toecological, Social and Economic Sustainability?" Ambio, Vol. 31, No. 4, 2002, pp. 311-323.

[13] J. H. Primavera, "Overcoming the Impacts of Aquaculture on the Coastal Zone," Ocean and Coastal Management, Vol. 49, No. 9-10, 2006, pp. 531-545. http://dx.doi.org/10.1016/j.ocecoaman.2006.06.018

[14] K. Rajitha, C. K. Mukherjee and R. Vinu-Chandran, "Applications of Remote Sensing and GIS for Sustainable Management of Shrimp Culture in India," Aquacultural Engineering, Vol. 36, No. 1, 2007, pp. 1-17. http://dx.doi.org/10.1016/j.aquaeng.2006.05.003

[15] C. T. Eng, J. N. Paw and F. Y. Guarin, "The Environmental Impact of Aquaculture and the Effects of Pollution on Coastal Aquaculture Development in Southeast Asia," Marine Pollution Bulletin, Vol. 20, No. 7, 1989, pp. 335343. http://dx.doi.org/10.1016/0025-326X(89)90157-4

[16] R. L. Naylor, R. J. Goldburg, H. Mooney, M. Beveridge, J. Clay, C. Folke, N. Kautsky, J. Lubchenco, J. Primavera and M. Williams, "Nature's Subsidies to Shrimp and Salmon Farming," Science, Vol. 282, No. 5390, 1998, pp. 883-884. http://dx.doi.org/10.1126/science.282.5390.883

[17] R. L. Naylor, R. J. Goldburg, J. H. Primavera, N. Kautsky, M. C. M. Beveridge, J. Clay, C. Folke, J. Lubchenco, H. Mooney and M. Troell, "Effect of Aquaculture on World Fish Supplies," Nature, Vol. 405, No. 6790, 2000, pp. 1017-1024. http://dx.doi.org/10.1038/35016500

[18] Z. Xu, J. H. Primavera, L. D. De La Peña, P. Pettit, J. Belak and A. Alcivar-Warren, "Genetic Diversity of Wild and Cultured Black Tiger Shrimp (Penaeusmonodon) in the Phillipines Using Microsatellites," Aquaculture, Vol. 199, No. 1-2, 2001, pp. 13-40. http://dx.doi.org/10.1016/S0044-8486(00)00535-4

[19] O. V. Sousa, A. Macrae, F. G. R.Menezes, N. C. M. Gomes, R. H. S. F. Vieira and L. C. S. Mendonça-Hagler, "The Impact of Shrimp Farming Effluent on Bacterial Communities in Mangrove Waters, Ceará, Brazil," $M a-$ rine Pollution Bulletin, Vol. 52, No. 12, 2006, pp. 17251734.http://dx.doi.org/10.1016/j.marpolbul.2006.07.006

[20] P. Moles and J. Bunge, "Shrimp Farming in Brazil: An Industry Overview," Report prepared under the World Bank, NACA, WWF and FAO Consortium Program on Shrimp Farming and the Environment. Work in Progress for Public Discussion. Published by the Consortium, 2002, $26 \mathrm{p}$.

[21] I. P. Rocha, "Current Status and Trends in Brazilian Shrimp Farming," Infofish International, Vol. 5, 2011, pp. 24-28.

[22] B. T. Poulos, K. F. J. Tang, C. R. Pantoja, J. R. Bonami and D. V. Ligthner, "Purification and Characterization of Infectious Myonecrosis Virus of Penaeid Shrimp," Jour- 
nalof General Virology, Vol. 87, 2006, pp. 987-996.

[23] M. A. Teixeira-Lopes, P. R. N. Vieira-Girão, J. E. C. Freire, I. R. C. B. Rocha, F. H. F. Costa and G. RádisBaptista, "Natural Co-Infection with Infectious Hypodermal and Hematopoietic Necrosis Virus (IHHNV) and Infectious Myonecrosis Virus (IMNV) in Litopenaeus vannamei in Brazil," Aquaculture, Vol. 312, No. 1-4, 2011, pp. 212-216. http://dx.doi.org/10.1016/j.aquaculture.2011.01.005

[24] R. V. Marins, F. J. Paula Filho, S. A. Eschrique and L. D. Lacerda, "Anthropogenic Sources and Distribution of Phosphorus in Sediments from the Jaguaribe River Estuary, NE, Brazil," Brazilian Journal of Biolology, Vol. 71, No. 3, 2011, pp. 673-678. http://dx.doi.org/10.1590/S1519-69842011000400011

[25] M. C. S. Abreu, P. Mattos, P. E. S. Lima and A. D. Padula, "Shrimp Farming in Coastal Brazil: Reasons for Market Failure and Sustainability Challenges," Ocean and Coastal Management, Vol. 54, No. 9, 2011, pp. 658667. http://dx.doi.org/10.1016/j.ocecoaman.2011.06.012

[26] N. Golafshani, "Understanding Reliability and Validity in Qualitative Research," The Qualitative Report, Vol. 8, No. 4, 2003, pp. 597-607.

[27] APHA, "Standard Methods," 19th Edition, American Public Health Association, Washington DC, 1995.

[28] A. M. L. Soares, M. S. B. S. Carvalho, R. N. C. Barreto and Z. M. L. Soares, "Análise Temporal do Crescimento da Carcinicultura Marinha no Estuário do rio JaguaribeCeará," In: J. C. N. Epiphanio, L. S. Galvão and L. M. G. Fonseca, Eds., Anais do XIII Simpósio Brasileiro de Sensoriamento Remoto-SBSR, INPE, Florianópolis, 2007, pp. 4267-4274.

[29] P. T. Anh, C. Kroeze, S. R. Bush A. P. J. Mol, "Water Pollution by Intensive Brackish Shrimp Farming in South-East Vietnam: Causes and Options for Control," Agricultural Water Management, Vol. 97, No. 6, 2010, pp. 872-882.

http://dx.doi.org/10.1016/j.agwat.2010.01.018

[30] T. P. D. Andrade, T. Srisuvan, K. J. F. Tang and D. V. Ligthner, "Real-Time Reverse Transcription Polymerase Chain Reaction Assay Using TaqMan Probe for Detection and Quantification of Infectious Myonecrosis Virus (IMNV)," Aquaculture, Vol. 264, No. 1-4, 2007, pp. 915. http://dx.doi.org/10.1016/j.aquaculture.2006.11.030

[31] D. V. Lightner, "Virus Diseases of Farmed Shrimp in the Western Hemisphere (the Americas): A Review," Journal of Invertebrate Pathology, Vol. 106, No. 1, 2011, pp. 110-130. http://dx.doi.org/10.1016/j.jip.2010.09.012

[32] M. A. Teixeira-Lopes, J. E. F. Cruz, P. R. N. Vieira, I. R. C. B. Rocha, F. H. F. Costa and G. Rádis-Baptista, "Differential Diagnosis of Active Hypodermal and Hematopoietic Necrosis Virus Based on Gene Choice and Reverse Transcription Coupled with PCR," Genetics and Molecular Research, Vol. 9, No. 4, 2010, pp. 2025-2031. http://dx.doi.org/10.4238/vo19-4gmr917

[33] J. H. Primavera, "Intensive Prawn Farming in the Philippines: Ecological, Social and Economic Implications," Ambio, Vol. 20, No. 1, 1991, pp. 28-33.

[34] F. Páez-Osuna, A. Gracia, F. Flores-Verdugo, L. P.
Lyle-Fritch, R. Alonso-Rodraguez, A. Roque and A. C. Ruiz-Fernandez, "Shrimp Aquaculture Development and the Environment in the Gulf of California Ecoregion," Marine Pollution Bulletin, Vol. 46, No. 7, 2003, pp. 806815. http://dx.doi.org/10.1016/S0025-326X(03)00107-3

[35] S. Alam, B. Pokrant, A. Yakupitiyage and M. Phillips, "Economic Returns of Disease Affected Extensive Shrimp Farming in Southwest Bangladesh," Aquaculture International, Vol. 15, No. 5, 2007, pp. 363-370. http://dx.doi.org/10.1007/s10499-007-9100-7

[36] A. K. Deb, "Fake Blue Revolution: Environmental and Socio-Economic Impacts of Shrimp Culture in the Coastal Areas of Bangladesh," Ocean and Coastal Management, Vol. 41, No. 1, 1998, pp. 63-88. http://dx.doi.org/10.1016/S0964-5691(98)00074-X

[37] J. Yamprayoon and K. Sukhumparnich, "Thai Aquaculture: Achieving Quality and Safety through Management and Sustainability," Journal of World Aquaculture Society, Vol. 41, No. 2, 2010, pp. 274-280. http://dx.doi.org/10.1111/j.1749-7345.2010.00355.x

[38] M. A. Wahab, A. Bergheim and B. Braaten, "Water Quality and Partial Mass Budget in Extensive Shrimp Ponds in Bangladesh," Aquaculture, Vol. 218, No. 1-4, 2003, pp. 413-423.

http://dx.doi.org/10.1016/S0044-8486(03)00009-7

[39] J. T. Ponce-Palafox, A. Ruiz-Luna, S. M. Castillo-Vargas, M. García-Ulloa and J. L. Arredondo-Figueroa, "Technical, Economics and Environmental Analysis of Semi-Intensive Shrimp (Litopenaeusvannamei) Farming in Sonora, Sinaloa and Nayarit States, at the East Coast of the Gulf of California, México," Ocean and Coastal Management, Vol. 54, No. 7, 2011, pp. 507-513.

http://dx.doi.org/10.1016/j.ocecoaman.2011.03.008

[40] S. K. Meltzoff and E. LiPuma, "The Social and Political Economy of Coastal Zone Management: Shrimp Mariculture in Ecuador," Coastal Zone Management Journal, Vol. 14, No. 4, 1986, pp. 349-380. http://dx.doi.org/10.1080/08920758609362009

[41] S. Ito, "From Rice to Prawns: Economic Transformation and Agrarian Structure in Rural Bangladesh," Journal Peasant Studies, Vol. 29, No. 2, 2002, pp. 47-70. http://dx.doi.org/10.1080/714003949

[42] A. Azad, K. Jensen and C. Lin, "Coastal Aquaculture Development in Bangladesh: Unsustainable and Sustainable Experiences," Environmental Management, Vol. 44, No. 4, 2009, pp. 800-809. http://dx.doi.org/10.1007/s00267-009-9356-y

[43] B. G. Paul and C. R. Vogl, "Impacts of Shrimp Farming in Bangladesh: Challenges and Alternatives," Ocean and Coastal Management, Vol. 54, No. 3, 2011, pp. 201-211. http://dx.doi.org/10.1016/j.ocecoaman.2010.12.001

[44] M. R. P. Briggs and S. J. Funge-Smith, "A Nutrient Budget of Some Intensive Marine Shrimp Ponds in Thailand," Aquaculture and Fisheries Management, Vol. 25, No. 8, 1994, pp. 789-811.

[45] J. Goss, D. Burch and R. Rickson, "Agri-Food Restructuring and Third World Transnationals: Thailand, the CP Group and the Global Shrimp Industry," World Development, Vol. 28, No. 3, 2000, pp. 513-530. 
http://dx.doi.org/10.1016/S0305-750X(99)00140-0

[46] M. Huitric, C. Folke and N. Kautsky, "Development and Government Policies of the Shrimp Farming Industry in Thailand in Relation to Mangrove Ecosystems," Ecological Economics, Vol. 40, No. 3, 2002, pp. 441-455. http://dx.doi.org/10.1016/S0921-8009(02)00011-3

[47] S. Veuthey and J. F. Gerber, "Accumulation by Dispossession in Coastal Ecuador: Shrimp Farming, Local Resistance and the Gender Structure of Mobilizations," Global Environmental Change, Vol. 22, No. 3, 2011, pp. 611-622. http://dx.doi.org/10.1016/j.gloenvcha.2011.10.010

[48] L. S. Queiroz, "There Is So Much Mangrove in the Life of Cumbe: The Influences of the Social-Environmental Impacts of Shrimp Farming on the Way of Life of a Coastal Community," Dissertation of Masters in Development and Environment-Graduate Program in Development and Environment, Federal University of Ceará, Fortaleza, 2007, pp. 113.

[49] W. Keithly and P. Poudel, "The Southeast U.S.A. Shrimp Industry: Issues Related to Trade and Antidumping Duties," Marine Resource Economics, Vol. 23, No. 4, 2008, pp. 459-483.

[50] S. J. Foster and A. C. J. Vincent, "Tropical Shrimp Trawl Fisheries: Fishers' Knowledge of and Attitudes about a Doomed Fishery," Marine Policy, Vol. 34, No. 3, 2010, pp. 437-446. http://dx.doi.org/10.1016/j.marpol.2009.09.010

[51] B. Muangkeow, K. Ikejima, S. Powtongsook and Y. Yi, "Effects of White Shrimp, Litopenaeus vannamei (Boone), and Nile Tilapia, Oreochromis niloticus L., Stocking Density on Growth, Nutrient Conversion Rate and Economic Return in Integrated Closed Recirculation System," Aquaculture, Vol. 269, No. 1-4, 2007, pp. 363-376. http://dx.doi.org/10.1016/j.aquaculture.2007.04.002

[52] M. A. Salam, L. G. Ross and M. C. M. Beveridge, "A Comparison of Development Opportunities for Crab and Shrimp Aquaculture in Southwestern Bangladesh, Using GIS Modeling," Aquaculture, Vol. 220, No. 1-4, 2003, pp. 477-494.

http://dx.doi.org/10.1016/S0044-8486(02)00619-1

[53] D. H. Giap, Y. Yi and A. Yakupitiyage, "GIS for Land Evaluation for Shrimp Farming in Haiphong of Vietnam," Ocean and Coastal Management, Vol. 48, No. 1, 2005, pp. 51-63.

http://dx.doi.org/10.1016/j.ocecoaman.2004.11.003

[54] R. R. Freitas, C. Hartmann, P. R. A. Tagliani and L. H. Poersch, "Evaluation of Space Adequateness of Shrimp Farms in Southern Brazil," Annals of the Brazilian Academy of Sciences, Vol. 83, No. 3, 2011, pp. 1069-1076. http://dx.doi.org/10.1590/S0001-37652011005000024

[55] M. A. Chowdhury, G. P. Shivakoti and M. Salequzzaman, "A Conceptual Framework for the Sustainability Assess- ment Procedures of the Shrimp Aquaculture Industry in Coastal Bangladesh," International Journal of Agricultural Resources, Governance and Ecology, Vol. 5, No. 2/3, 2006, pp. 162-184.

[56] N. Ahmed, H. Demaine and J. F. Muir, "Freshwater Prawn Farming in Bangladesh: History, Present Status and Future Prospects," Aquaculture Research, Vol. 39, No. 8, 2008, pp. 806-819. http://dx.doi.org/10.1111/j.1365-2109.2008.01931.x

[57] C. A. Berlanga-Robles, A. Ruiz-Luna, G. Bocco and Z. Vekerdy, "Spatial Analysis of the Impact of Shrimp Culture on the Coastal Wetlands on the Northern Coast of Sinaloa, Mexico," Ocean and Coastal Management, Vol. 54, No. 7, 2011, pp. 535-543. http://dx.doi.org/10.1016/j.ocecoaman.2011.04.004

[58] D. A. Ziemann, W. A. Walsh, E. G. Saphore and K. Fulton-Bennet, "A Survey of Water Quality Characteristics of Effluent from Hawaiian Aquaculture Facilities," Journal of World Aquaculture Society, Vol. 23, No. 3, 1992, pp. 180-191. http://dx.doi.org/10.1111/j.1749-7345.1992.tb00767.x

[59] S. J. Funge-Smith and M. R. P. Briggs, "Nutrient Budgets in Intensive Shrimp Ponds: Implications for Sustainability," Aquaculture, Vol. 164, No. 1-4, 1998, pp. 117-133. http://dx.doi.org/10.1016/S0044-8486(98)00181-1

[60] L. A. Trott and D. M. Alongi, "The Impact of Shrimp Pond Effluent on Water Quality and Phytoplankton Biomass in a Tropical Mangrove Estuary," Marine Pollution Bulletin, Vol. 40, No. 11, 2000, pp. 947-951. http://dx.doi.org/10.1016/S0025-326X(00)00035-7

[61] B. Xie, Z. H. Ding and X. R. Wang, "Impact of the Intensive Shrimp Farming on the Water Quality of the Adjacent Coastal Creeks from Eastern China," Marine Pollution Bulletin, Vol. 48, No. 5-6, 2004, pp. 543-553. http://dx.doi.org/10.1016/j.marpolbul.2003.10.006

[62] S. D. Costanzo, M. J. O’Donohue and W. C. Dennison, "Assessing the Influence and Distribution of Shrimp Pond Effluent in a Tidal Mangrove Creek in North-East Australia," Marine Pollution Bulletin, Vol. 48, No. 5-6, 2004, pp. 514-525.

http://dx.doi.org/10.1016/j.marpolbul.2003.09.006

[63] R. Casillas-Hernández, F. Magallón-Barajas, G. PortilloClarck and F. Páez-Osuna, "Nutrient Mass Balances in Semi-Intensive Shrimp Ponds from Sonora, Mexico Using Two Feeding Strategies: Trays and Mechanical Dispersal," Aquaculture, Vol. 258, No. 1-4, 2006, pp. 289298. http://dx.doi.org/10.1016/j.aquaculture.2006.03.027

[64] Y. Thomas, C. Courties, Y. E. Helwe, A. Herbland and H. Lemonnier, "Spatial and Temporal Extension of Eutrophication Associated with Shrimp farm Wastewater Discharges in the New Caledonia Lagoon," Marine Pollution Bulletin, Vol. 61, No. 7-12, 2010, pp. 387-398. 